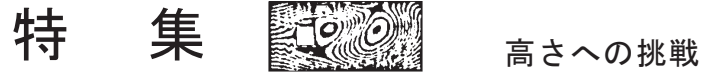

\section{0 m建物の耐風設計一あベのハルカスー Wind Resistant Design of 300 meter Building - ABENO HARUKAS -}

\author{
九嶋 壮一郎 ${ }^{* 1}$ \\ 平川恭章 ${ }^{* 1}$ \\ 大竹和夫 ${ }^{* 2}$
}

Soichiro KUSHIMA， Kiyoaki HIRAKAWA，Kazuo OHTAKE

1.はじめに

建物高さ $300 \mathrm{~m}$ と超高層ビルとして日本一の高さとな る「あべのハルカス」では地震・強風時の安全性を確保 するためにさまざまな取り組みを実施している。本報告 では，主に強風時の安全性・居住性に関する新技術の適 用や検証・設計方法を中心に述べる。

\section{2. 建物概要}

本建物は，大阪市阿倍野区の近鉄南大阪線のターミナ 儿駅である阿部野橋駅西側に位置寸る近鉄百貨店（旧館） の建替え（以下，タワー館と呼ぶ）であり，駅上部の既 存の百貨店である本館の改修とともに計画されている。 表 1 に建物概要，図 1 に東西断面図，図 2 に北西からの 外観写真を示す。

\section{表 1 建物概要}

\begin{tabular}{ll}
\hline 所在地 & 大阪市阿倍野区阿倍野筋 1 丁目 \\
事業主 & 近畿日本鉄道株式会社 \\
構造 & $\mathrm{S}, \mathrm{SRC}$ \\
階数 & 地上 60 階、地下 5 階 (タワー館部分) \\
建築面積 約 $6,100 \mathrm{~m}^{2}$ (タワー館部分) \\
延床面積 約 $212,000 \mathrm{~m}^{2}$ (タワー館部分) \\
高さ $\quad$ 地上 $300 \mathrm{~m}$
\end{tabular}

タワー館は, 地上 60 階, 地下 5 階, 搭屋 1 階であり, それぞれ高さ約 $100 \mathrm{~m}$ の低層・中層・高層の 3 つのブロ ックから構成されている。低層部には百貨店，中層部に は美術館およびオフィス，高層部にはホテルおよび展望 台がそれぞれ配置されている。

各ブロックは上層部ほどセットバックし，各ブロック の境界部は階高 $10 \mathrm{~m}$ 前後のトラス階としている。トラス 階は主に設備機械室として利用している。

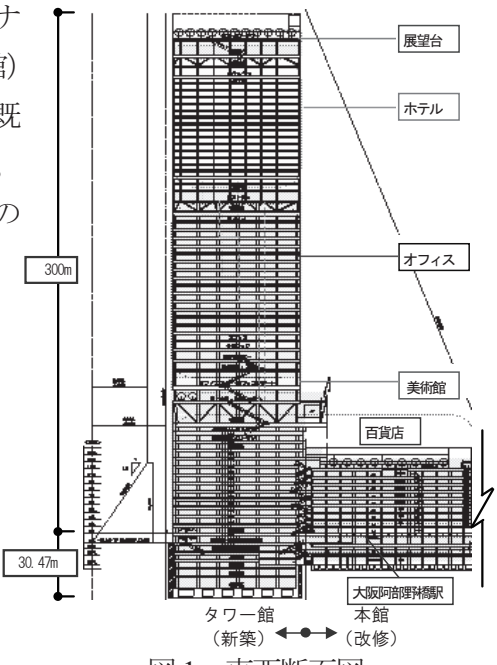

困 1 東西断面図

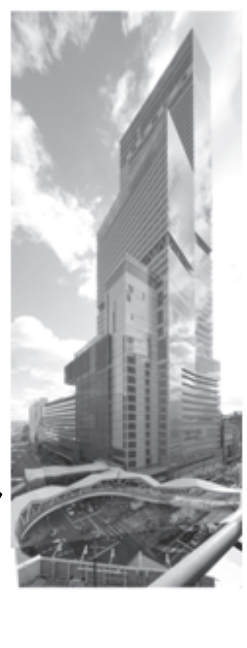

図 2 北西からの 外観写真

* 1 株式会社竹中工務店 設計部構造部門

Structural Engineering Section, Building Design Department, Takenaka Corporation

*2 株式会社竹中工務店 技術研究所

Research \& Development Institute, Takenaka Corporation 
3. 構造計画概要・耐震設計

本建物は通常の高層建物で設定される而力関係のクラ イテリアを1ランク向上させることを設計方針としてい る。表 2 に設計クライテリア (地震動) を示す。各部材 はレベル 2 までは塑性化を許容せず, 余裕度検討用レベ ルでは梁・ブレースのみ塑性化を許容している。建物の 曲げ・回転を含めた層間変形角は, レベル 2 に対して 10 $\times 10^{-3}$ 以下，余裕度検討用レベル地震動に対して $13.5 \times$ $10^{-3}(\fallingdotseq 1 / 75)$ 以下としている。

構造概念図を図 3 に示寸。中・低層階の柱には超高強 度コンクリートと鋼材を組み合わせた国内最高級の CFT 柱を採用し，基礎構造にはパイルド・ラフト基礎を採用 している。低層・中層・高層境界部と高層部直上にはト ラス階を設けている。さらに中層オフィス部分にアウト リガーブレースを配置し曲げ戻し効果を期待している。

低層部には粘性系オイルダンパーと履歴系回転摩擦ダ ンパーを配置し, 中層部は波型鋼板耐震壁（東西方向） と耐震ブレース（南北方向）を配置している。高層部は 東西方向をラーメン架構とし, 南北方向はホテル客室戸 境壁内に耐震ブレースを設け, 吹抜部に心棒ダンパーを 配置している。ハットトラス階には居住性改善のために マスダンパー(ATMD)を配置している。

而震設計に用いる入力地震動は 3 種類に分類される。 第一は, 平成 12 年建設省告示 1461 号に規定される地震 動である(以下告示波)。告示波は「稀に発生する地震動」 (レベル 1)と「極めて稀に発生する地震動」(レベル 2)につ いて 3 種類作成する。さらに従来用いてきた Elcentro 1940 $\mathrm{NS}$ 等の 3 波 (以下標準波) を最大速度振幅 $25 \mathrm{~cm} / \mathrm{s}$ ( レ ベル 1), $50 \mathrm{~cm} / \mathrm{s}$ (レベル 2)とし採用する。

第二は, 余裕度検討用の地震動としてレベル 2 告示 波の基盤波を 1.5 倍し 3 波作成する。

第三は，地域性を考慮した地震波である。南海トラ フの海溝型地震のうち, 南海地震単独発生時および南 海地震と東南海地震の連動発生時の模擬地震動を作成

表 2 設計クライテリア (地震動)

\begin{tabular}{|c|c|c|c|c|}
\hline \multirow{2}{*}{\multicolumn{2}{|c|}{ 地震動の概要 }} & レベル1 & レベル2 & 余裕度検討用レベル \\
\hline & & $\begin{array}{l}\cdot \text { ·稀に発生する } \\
\text { 地震動 } \\
\text { ·再現期間約 } 50 \text { 年 }\end{array}$ & $\begin{array}{l}\cdot \text { 極めて稀に } \\
\text { 発生する地震動 } \\
\text { ·再現期間約500年 }\end{array}$ & ·告示レベル $2 \times 1.5$ 倍 \\
\hline \multicolumn{2}{|c|}{ 目標とする建物性能 } & 実用性(継続使用可能) & 健全性(補修可能) & 修復性(補強可能) \\
\hline \multirow{2}{*}{\begin{tabular}{l|} 
上 \\
部 \\
構 \\
造 \\
\end{tabular}} & 層間変形角 & $5.00 \times 10^{-3} \mathrm{rad}$ & $10.00 \times 10^{-3} \mathrm{rad}$ & $13.50 \times 10^{-3} \mathrm{rad}$ \\
\hline & 層の塑性率 & 短期許容応力度以下 & 1.0以下 & 2.0以下 \\
\hline \multirow{2}{*}{$\begin{array}{l}\text { 基 } \\
\text { 礎 } \\
\text { 構 } \\
\text { 造 }\end{array}$} & $\begin{array}{c}\text { 地下架構 } \\
\cdot \text { ·基䃈 }\end{array}$ & 短期許容応力度以下 & 終局強度未満 & $\begin{array}{c}\text { 地下架構は } \\
\text { 部材塑性率 }<4.0 \\
\text { 基整・杭は終局強度以下 }\end{array}$ \\
\hline & 杭の支持力 & 短期許容支持力以下 & 短期許容支持力以下 & 極限支持力以下 \\
\hline
\end{tabular}

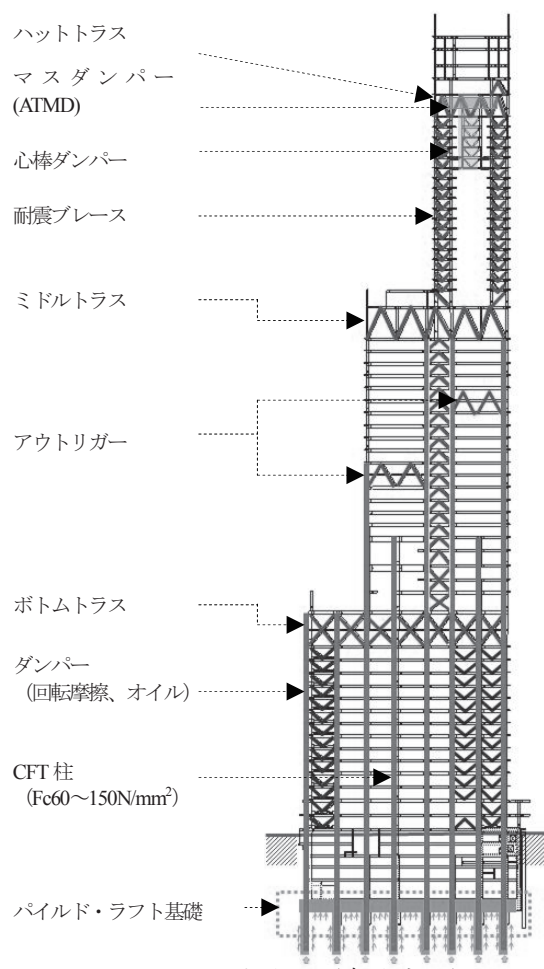

図 3 構造計画（南北方向）

する ${ }^{1,2)}$ 。さらに, 上町断層帯について大振幅の地震波が 入射するようアスペリティを設定したケース 1 と長周期 成分が生成されるように南北に細長くアスペリティを設 定したケース 2 の模擬地震動を作成する ${ }^{2}$ 。

図 4 に地震動の速度応答スペクトルと建物の南北方向 固有周期を示寸。様々な特性を有する地震動について設 計クライテリアを満足することを確認している。
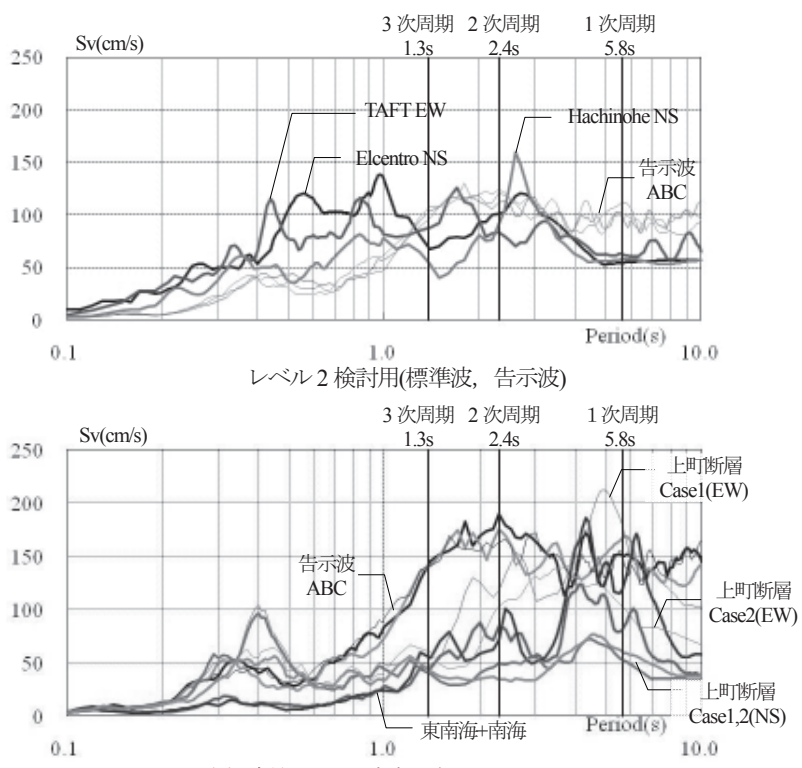

余裕度検討用(地域波, 告示レベル $2 \times 1.5)$

図 4 速度応答スペクトル(減衰定数 $\mathrm{h}=0.05$ ) 
4. 而風設計

4. 1 設計クライテリア

耐風設計の検討項目およびクライテリアを表 3 に示す。 再現期間 500 年の風をレベル 2 とし，レベル 2 での部材 塑性化を許容しない方針としている。

\section{2 而風計画}

塔状の形状を有する超高層建物では固有周期が長くな るのに伴い風直交方向の荷重が大きく増加し, 設計上も 支配的となる場合がある。本建物では建物全体計画から 部材計画の範囲まで以下の3つの取り組みを行っている。 1) 風の影響を低減する「かたち」

風直交方向およびねじれ方向の変動風力は建物形状に 大きく依存している ${ }^{3), 4)}$ 。本建物では南北方向入建物形状 をセットバックさせることにより高さ方向に発生するカ ルマン渦の周期を変化させ，一般的な四角形(Square)形状 を採用した場合に比べ風直交方向の変動風力を抑制して いる。図 5 に建物形状による風荷重の比較例を示す。

低中高層各ブロックの建物用途・外観デザインと融合
した「かたち」の実現が而風計画の要となっている。

2) 水平・ねじれ剛性を高めた「架構」

風外力やねじれモーメントに対して建物の変形を抑制 するために，アウトリガートラスの配置と建物外周部 のせん断間柱の配置を行い強固な架構を形成している。 表 4 に建物固有周期，図 6 に架構パースを示す。強固な 架構は建物固有周期を短くしており，風荷重の低減に寄 与している。また，ねじれ岡性の確保により建物並進周 期とねじれ周期が近接せず，二つの振動の連成を生じに くくしている。

3) 各部の付加減衰を確保するための「機構

安全性確保や後述する空力不安定振動の発生抑制なら びに居住性確保のためには減衰性能の向上が重要となる。

本建物では図 6 に示すように低・中・高層各ブロック にバランス良く制振部材・機構を配置し建物減衰性能を 確保している。また，頂部ハットトラスには強風時の居 住性を確保するために AMD/ATMD を設置している。

表 3 検討項目と設計クライテリア（風）

\begin{tabular}{|c|c|c|c|c|c|c|}
\hline \multirow{2}{*}{\multicolumn{2}{|c|}{ 検討項目 }} & \multirow{2}{*}{ 設計風速 ${ }^{* 1}$} & \multicolumn{2}{|c|}{ 風荷重の算定方法 } & \multirow{2}{*}{\multicolumn{2}{|c|}{ クライテリア }} \\
\hline & & & 平均荷重 & 変動荷重 & & \\
\hline \multirow{4}{*}{ 安全 } & \multirow{2}{*}{ 構造骨組用 } & $\begin{array}{l}\mathrm{Vo}=34 \mathrm{~m} / \mathrm{sec} . \\
(レ ヘ ゙ ル 1 \text { 再現期間 } 50 \text { 年 })\end{array}$ & \multirow{2}{*}{ 風洞実験（風圧測定） } & \multirow{2}{*}{$\begin{array}{l}\text { スペクトルモーダル法 } \\
\text { 荷重組合は指針 }{ }^{1} \text { 準拠 }\end{array}$} & レベル 1 & $\begin{array}{l}\text { 短期許容応力度以下 } \\
\text { 層間変形角 } 5.00 \times 10^{-3} \mathrm{rad} \text {. 以下 }\end{array}$ \\
\hline & & $\begin{array}{l}\text { Voの } 1.25 \text { 倍 } \\
\text { (レベル2 再現期間 } 500 \text { 年) }\end{array}$ & & & レベル2 & $\begin{array}{l}\text { 塑性ヒンジを形成しない（終局耐力以下） } \\
\text { 層変形角 } 10.0 \times 10^{-3} \mathrm{rad} \text {. 以下 }\end{array}$ \\
\hline & \begin{tabular}{|c|} 
空力 \\
不安定振動
\end{tabular} & Voの1.5倍 & - & 多質点空力振動実験 & & 空力不安定振動を発生させない \\
\hline & 外装材用 & Voの1.1倍 & 風洞実験（風圧） & - & & ガラスが破損しない \\
\hline 安心 & 居住性検討 & $\begin{array}{c}\mathrm{Vo} \text { ○0.5倍 } \\
\text { (再現期間 } 1 \text { 年) }\end{array}$ & 風洞実験（風圧） & $\begin{array}{l}\text { スペクトルモーダル法 } \\
\text { 風向頻度考慮 }\end{array}$ & & H-30を満足 \\
\hline
\end{tabular}

表 4 Y 方向建物固有周期 (sec.)

\begin{tabular}{|c|c|c|c|}
\hline & 1次 & 2次 & 3次 \\
\hline $\mathrm{X}$ & 5.6 & 2.3 & 1.4 \\
\hline $\mathrm{Y}$ & 5.8 & 2.4 & 1.3 \\
\hline ねじれ & 3.9 & 1.8 & 1.3 \\
\hline
\end{tabular}

大きな風の渦が同時に発生

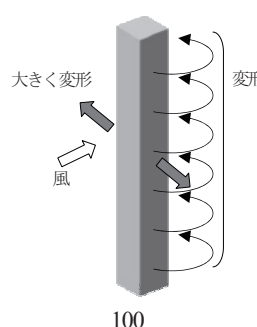

Square

影響が大きい高層部の渦が小さい 渦の発生時刻加各高さにて異なる

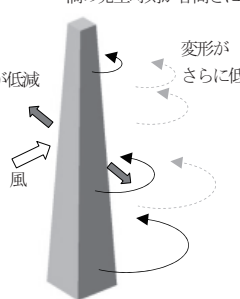

85

Taperd

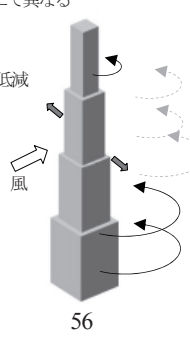

Setback
数值嫃椡モーメントの比老示寸。4)

図 5 「かたち」と風荷重の関係の比較

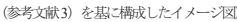

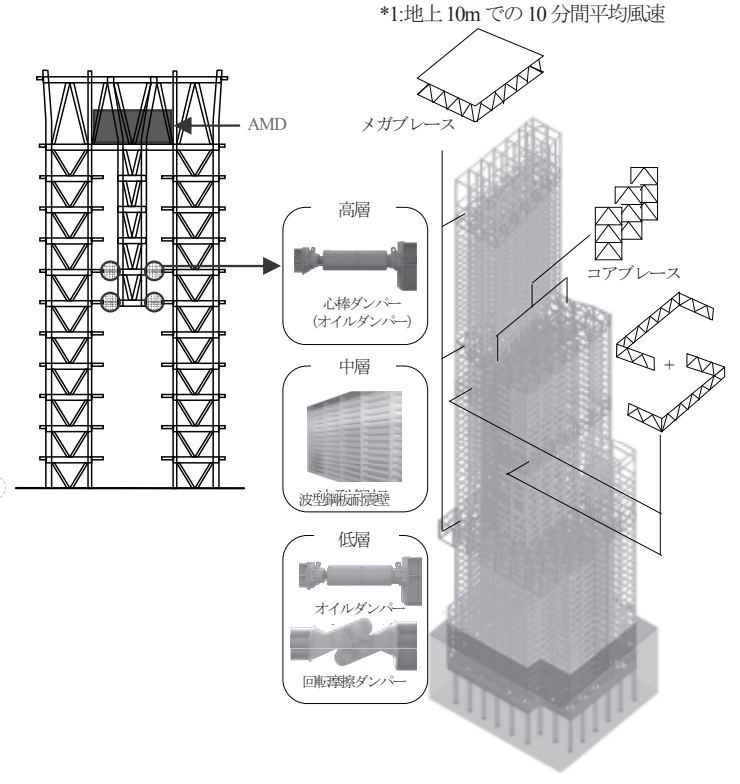

図 6 「架構」と各部「機構」 


\section{3 風洞実験概要}

4. 1 で示寸様々な耐風設計用の風荷重を求めるため に風洞実験を行った。図 7 に示寸実験模型の縮尺は $1 / 500$, 模型化範囲は半径 $700 \mathrm{~m}$ であり，圧力測定点は合計 624 点である。平面形状，風向の定義を図 8 亿示す。

風洞気流は, 荷重指針 ${ }^{5}$ の地表面粗度区分亚の気流を採 用した。基準高さ（地上 $300 \mathrm{~m}$ ，模型上 $616 \mathrm{~mm}$ ）での平 均風速は $11.8 \mathrm{~m} / \mathrm{s}$, 乱れの強さは $10 \%$ 程度である。平均風 速と乱れの強さの鉛直方向分布を図 9 に示寸。実験風向 はオフィス階の北壁面に正対する風向を $0^{\circ}$ とし, 時計回 りに $5^{\circ}$ 間隔で 72 風向とした。風圧の計測には多点同時 風圧測定システムを使用した。収録された外圧デー夕は チューブ系の周波数応答特性に基づき補正した。

\section{4 風荷重の算定}

変動荷重算定のために応答解析を行う。応答解析にお ける 1 次の一般化風力係数の時刻歴デー夕は層風力係数 の時刻歴データと各方向 1 次の振動モードを用い算定す る。層風力係数は建物頂部での速度圧 $q_{H}$, ホテル階長辺 $D\left(\right.$ 捩孔は $\left.D^{2}\right)$ で無次元化している。1 次の一般化変動風 力係数と風向角の関係を図 10 亿示寸。

図より，一般化変動風力係数は Y 方向は建物に正対す る風向で, 㧖れは長辺に並行となる風向で大きくなって おりともに風向 $270^{\circ}$ で最大となっている。風向 $180^{\circ}$ ， $270^{\circ}$ での 1 次の一般化変動風力のパワースペクトル密度

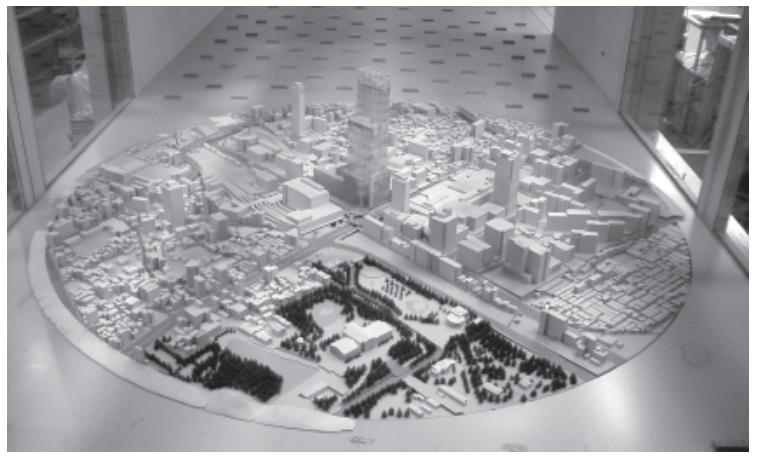

図 7 風洞実験模型（縮尺 $1 / 500 ）$

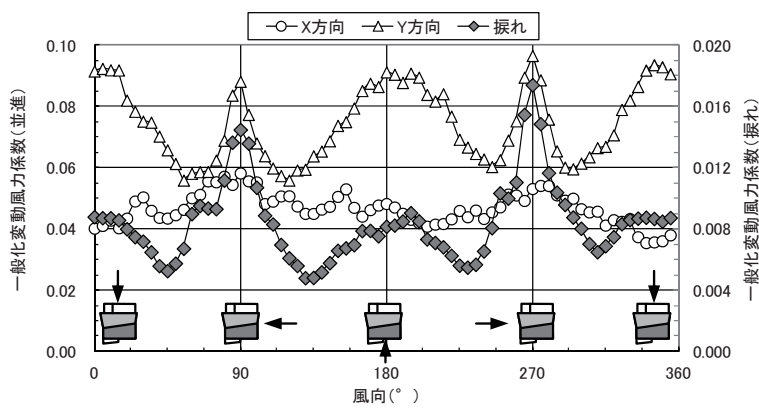

図 10 一般化変動風力係数之風向角の関係
を図 11 に示す。図の横軸は $D(=69.5 \mathrm{~m})$, での建物頂部 での風速 $U_{H}$ で無次元化した振動数を示している。図中の 破線は各方向の 1 次固有振動数 $f_{0}$, レベル 2 の建物頂部 での設計風速 $U_{H, L 2}(=66.6 \mathrm{~m} / \mathrm{s})$ から算出される無次元振動 数を表している。図より, 風直交方向（風向 $270^{\circ}$ の $\mathrm{Y}$ 方向）のパワースペクトル密度において，なだらかなピ ークが確認できるが，ピークとなる無次元振動数は $f_{0} D / U_{H, L 2}$ よりも小さい 0.1 程度であることがわかる。

レベル 2 風時の層せん断力は当該階以上の平均層風力 の総和である平均風荷重と 1 次の固有振動によって生じ る慣性力に相当する変動風荷重を足し合わせて算出した。 ここでの慣性力は，スペクトルモーダル法によって算出 される変動変位の標準偏差に, $\left(2 \pi f_{0}\right)^{2}$ およびピークファ クタを乗じて算出している。X方向および $\mathrm{Y}$ 方向のベー スシェアと風向角の関係を図 12 に示す。図より, Y 方向 のベースシェアは，建物に正対する風向で大きくなって おり，概ね風直交方向となる風向 $85^{\circ}$ で最大となっている。 $\mathrm{X}$ 方向および $\mathrm{Y}$ 方向の最大層せん断力分布を図 13 に, 最 大層間変形角分布を図 14 に示寸。風の影響を受けにくい 建物形状の採用, 強固な架構による固有周期の短縮によ り風荷重は殆どの階において地震荷重を下回る結果とな った。レベル 2 の最大層間変形角は 19 階で約 $1 / 150$ であ り，設計クライテリアである $1 / 100$ 以下となっている。

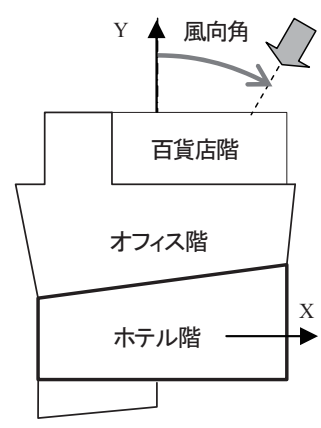

図 8 平面形状および 風向の定義

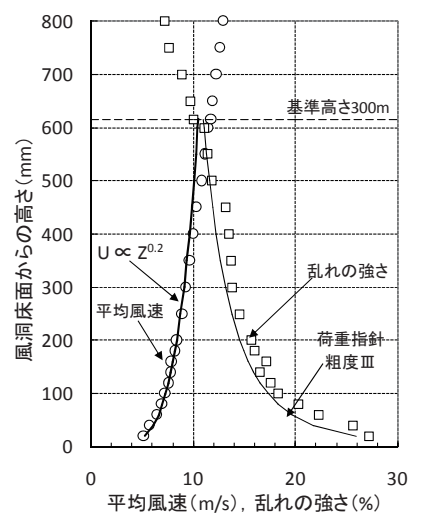

図 9 風洞気流
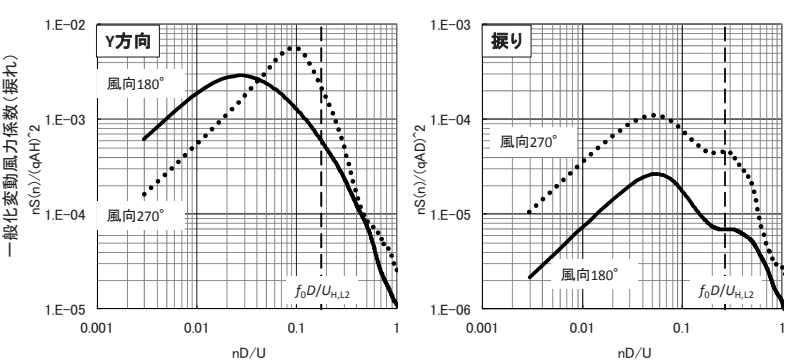

図 11 一般化変動風力係数のパワースペクトル密度 


\section{5 空力不安定振動に対する検討}

風圧測定実験から算出された風直交方向のカルマン 渦の発生周波数と Y 方向の固有振動数 $(=0.169 \mathrm{~Hz})$ が一 致する風速は $97.9 \mathrm{~m} / \mathrm{s}$ で, 再現期間 500 年相当の設計風速 $66.6 \mathrm{~m} / \mathrm{s}$ の 1.4 倍以上である。また本建物は，受圧面積が 大きいY 方向が風直交方向となる風向 $90^{\circ}$ および $270^{\circ}$ の場合には高さ方向に見附幅が変化し，空力不安定振動 が発生しにくい形態であると考えられる。

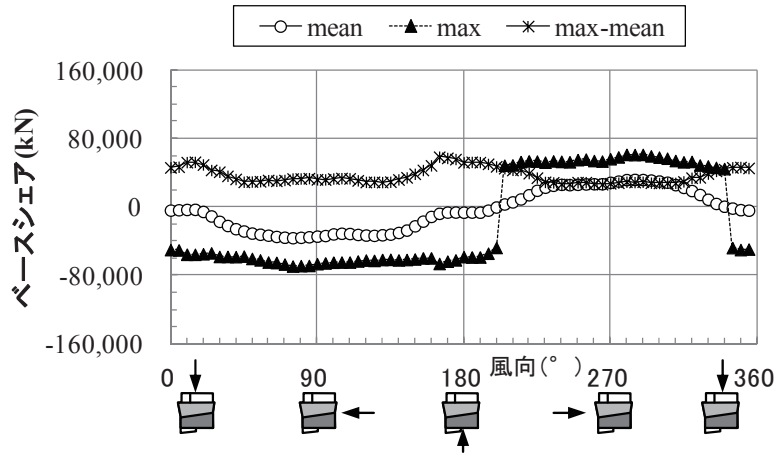

$\mathrm{X}$ 方向
しかし，ホテル階の平面形状が偏平でねじれ振動が懸念 されることから，図 15 に示す 5 質点立体模型を用いた空 力振動実験を行った。困 16 に示すように再現期間 500 年 相当のレベル 2 設計風速の 1.2 倍以下で空力不安定振動が 発生しないことを確認した。図より，X 方向は解析結果 とほぼ一致し，Y 方向は解析結果よりも振動実験結果が 小さく，空力正減衰が作用したものと推察される。

4. 6 居住性評価

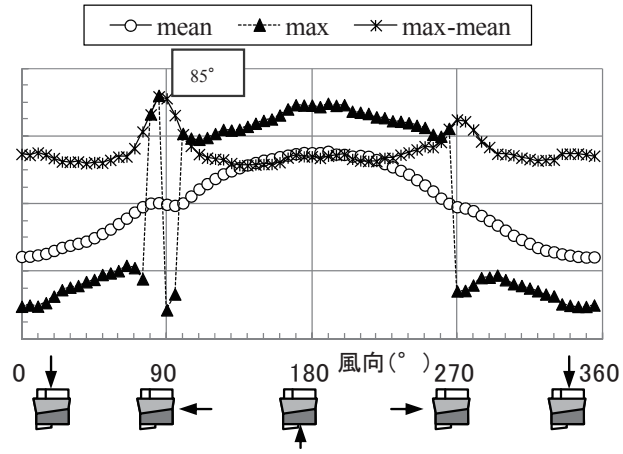

$\mathrm{Y}$ 方向

図 12 ベースシェアと風向角の関係（レベル 2）

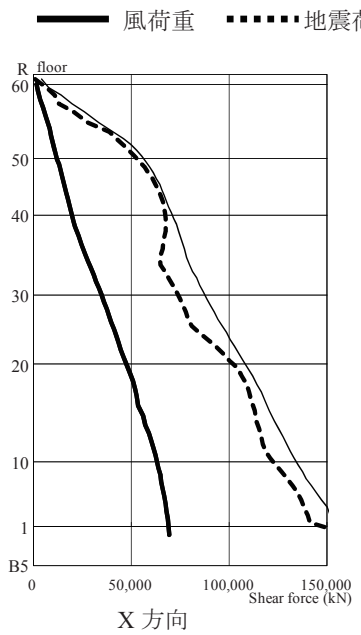

図 13 レベル 2 層せん断力分布
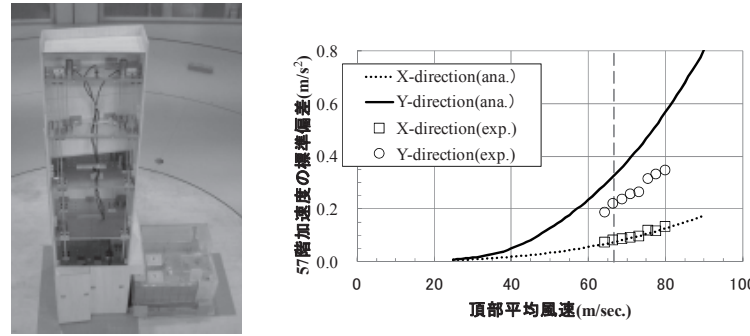

図 16 頂部平均風速と 57 階加速度関係

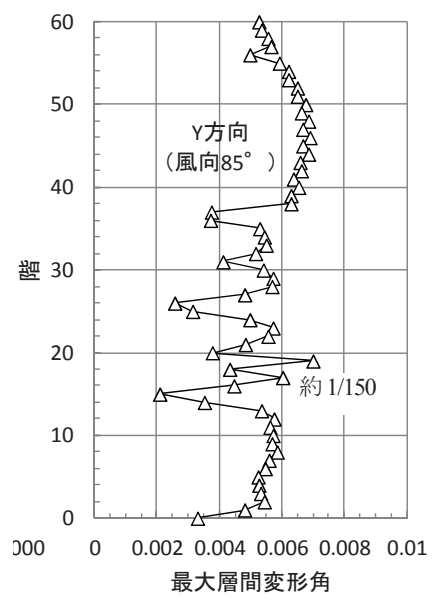

図 14 最大層間変形角分布 (レベル 2 風)

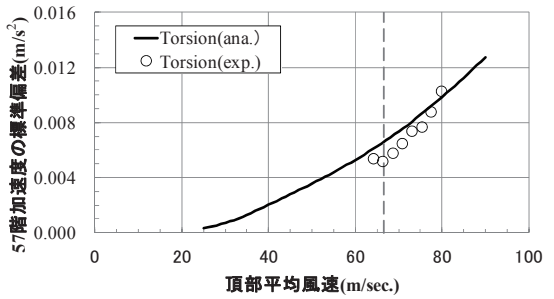

図 15 多質点振動模型概要

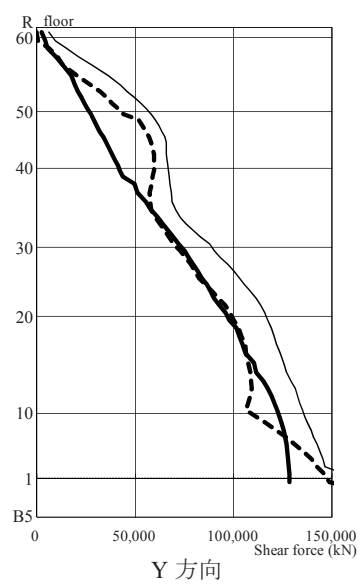


本建物では高層部にホテルが計画されており，再現期 間 1 年の応答加速度を $\mathrm{H}-30$ クラス ${ }^{0} に$ 抑え, 快適な居住 性を確保する必要がある。

建物長辺方向(東西方向)はダンパーがない状態でも H-30 クラスを確保寸ることが可能であるが，建物短辺方 向(南北方向)とねじれ振動に対しマスダンパーを用いる ことで居住性を向上させている。居住性能評価指針のに基 づき, 強風時の水平振動に関する居住性能を評価した結 果を図 17 に示寸。再現期間 1 年の最大加速度 ${ }^{5}$ は, 建設 地における風向毎の出現頻度, 風速分布を考慮して算定 している。南北方向・㸚じれともに設計クライテリアで ある H-30 を満足している。

マスダンパーはハットトラス階である 56 階の東西に 1 基ずつ設置する。下階に宿泊室を有する西側は振り子形 式としている。建物周期が約 6 秒と長いため従来の吊り 振り子を用いた場合, 振り子長さは $9 \mathrm{~m}$ に達寸る。本建 物では倒立振り子を組み合わせた形式として, 振り子長 さを約 $2.2 \mathrm{~m}$ とし, 非常にコンパクトな機構を実現してい る。図 18 に ATMD 外観を示寸。

\section{7 外装材設計用風荷重}

外装材設計用風荷重は再現期間 200 年相当の設計風速 に対して算出した。風荷重はセットバック部分が大きく, 16 階北東部で最大約 $10,000 \mathrm{~Pa}$ の負圧となり，15 mm+19 mm のフロートガラスを採用している。

\section{5.まとめ}

あべのハルカスでは超高層建物において影響が大きい 強風時の安全と安心の確保を目標として，「かたち」・架 構」・機構」を組み合わせた而風計画・設計を実施した。

これらの取り組みにより固有周期の短縮, 並進・ねじ れの固有周期の近接の防止，付加減衰の確保を実現した。
風荷重（骨組用）は概数地震荷重以下となり，強風時の 安全に対する冗長性を確保することが出来た。

謝辞

河井宏允京都大学名誉教授には, 而風設計全般に渡って 有益な御助言を頂いた。ここに感謝の意を表す。

\section{参考文献}

1) Irikura, K., "Prediction of strong acceleration motions using empirical Green's function", Proc. 7th Japan Earthq. Eng. Symp., pp. 151-156, (1986)

2) 大阪府, 「大阪府自然災害総合防災対策検討（地震被害 想定）報告書」, (2007.3)

3）田村幸雄,「風と制振」，建築技術, pp. 177-180, (1994.7)

4) 田村幸雄, 中井政義, 大竹和夫他，「新しい形態を有す る超々高層建築物の耐風設計手法に関する研究」, 国土 交通省平成 $20 \cdot 21$ 年度建設技術研究開発費補助金総合 研究報告書,

$<$ http://www.mlit.go.jp/tec/gijutu/kaihatu/josei/067houkoku.p df>, (2012.10.2)

5) 日本建築学会, 「建築物荷重指針・同解説」,(2004)

6) 日本建築学会,「建築物の振動に関する居住性能評価指 針・同解説」,(2004)

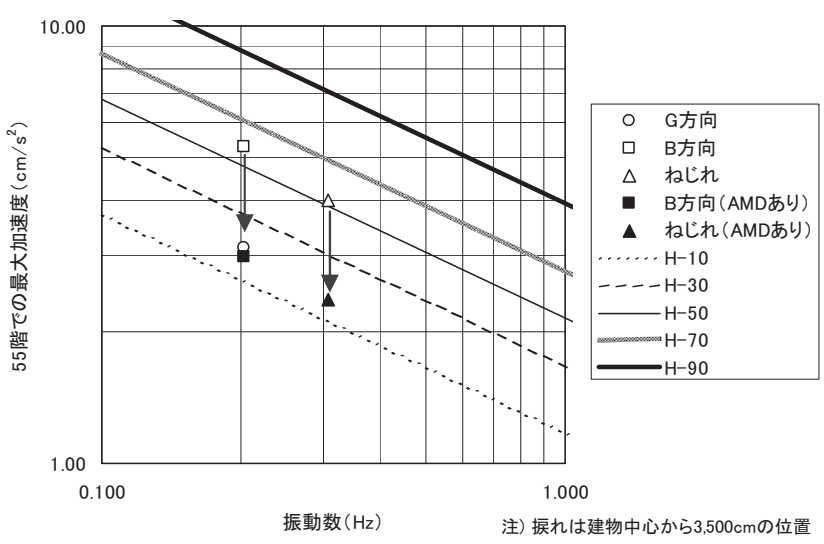

図 17 居住性能評価

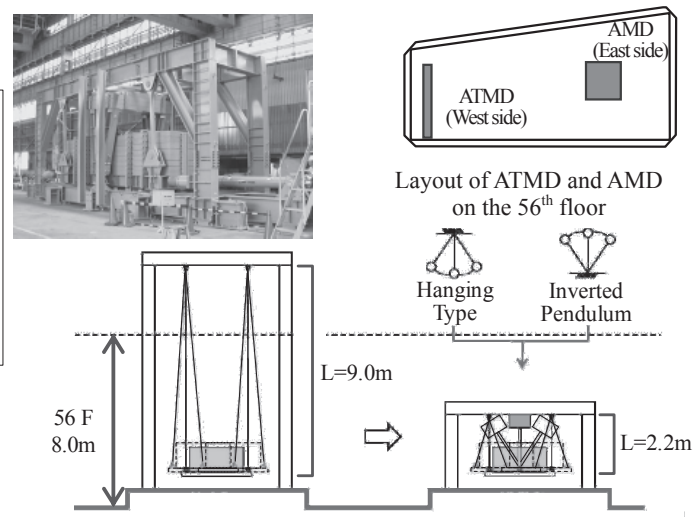

図 18 ATMD 外観, 配置 